\title{
Relational Model of Teacher Competence, Student Motivation and Learning Facilities on Learning Achievement.
}

\author{
Budiyono Pristyadi \\ Muhammad Syaiful Anam \\ Dept of Management, Faculty of Economics and Business, Universitas Muhammadiyah Gresik \\ Email : budiprestyo@umg.ac.id
}

\begin{abstract}
ABSTRAK
Pendidikan mempunyai peran yang sangat penting dalam membentuk sumber daya manusia, maka perlu adanya peningkatan mutu dalam dunia pendidikan. Peningkatan murtu pendidikan tidak terlepas dari keberhasilan proses belajar mengajar. Keberhasilan proses belajar mengajar dapat dilihat dari prestasi belajar siswa. Penelitian ini bertujuan untuk mengetahui pengaruh kompetensi guru, motivasi belajar siswa, fasilitas belajar terhadap prestasi belajar siswa. Populasi dalam penelitian ini adalah siswa tingkat akhir pada sekolah menengah kejuruan 161 siswa. penelitian ini menggunakan teknik pengambilan sampel yakni sampling insidental, sampel yang digunakan berjumlah 100 siswa, Jenis data yang digunakan adalah data primer, Pengujian dilakukan dengan menggunakan teknik analisis regresi linier berganda, hasil penelitian ini menunjukkan bahwa variabel kompetensi guru, motivasi belajar, dan fasilitas belajar secara parsial berpengaruh terhadap prestasi belajar.
\end{abstract}

Kata Kunci :Kompetensi Guru, Motivasi Belajar, Fasilitas Belajar, Prestasi Belajar

\begin{abstract}
Education has a very important role in shaping human resources, it is necessary to improve quality in the world of education. The increase in education lapsed can not be separated from the success of the teaching and learning process. The success of the teaching and learning process can be seen from student achievement. This study aims to determine the effect of teacher competence, student motivation, learning facilities on student achievement. The population in this study were final year students in 161 vocational high school students. This study uses a sampling technique that is incidental sampling, the sample used is 100 students, the type of data used is primary data, testing is done by using multiple linear regression analysis techniques, the results of this study indicate that the variables of teacher competency, learning motivation, and learning facilities partially affect learning achievement.
\end{abstract}

Keywords : Teacher Competence, Learning Motivation, Learning Facilities, Learning Achievement

\section{INTRODUCTION}

National education basically has a goal to educate the nation's life and try to develop Indonesia as a whole based on Pancasila and the 1945 Constitution. Education has the task to prepare quality human resources to carry out development and must be pursued in tune with the demands of the times. Human resource development has a very important role for the success and sustainability of development, therefore the development and improvement of the quality of human resources is absolutely necessary. In the context of human resource development, education is basically a teaching and learning process as stated in the Law of the Republic of Indonesia No. 20 of 2003 concerning the National Education System, stated in article 3 states that this educational unit is pursued in the framework of achieving national education goals, while the functions and objectives of national education are: national education functions to develop capabilities and shape the character and 
civilization of a dignified nation in order to educate life nation, aims to develop the potential of students to become human beings who believe and devote to God Almighty, noble, healthy, knowledgeable, creative, independent, and become citizens of a democratic and responsible.

Education has a very important role in shaping human resources, it is necessary to improve quality in the world of education. The increase in education lapsed can not be separated from the success of the teaching and learning process. The success of the teaching and learning process can be seen from student learning achievement, according to Arifin (2011; 12) learning achievement is generally related to aspects of knowledge that can be known through evaluation and realized in the form of numbers or values. According to Hamdani (2010: 138) learning achievement is the result of measurement of the learning effort assessment expressed in the form of symbols, letters, and sentences that tell the learning outcomes achieved by each child in a certain period. After tracing the description above it can be understood that learning achievement is the result that has been achieved by students after carrying out learning efforts.

National exams are the last stage that must be taken well by students, the role or performance of teachers greatly affect the success of students in taking a national exam. School data obtained from the sample, that the average test scores of Indonesian subjects are 62.7, English subjects are 49.8, mathematics subjects are 44.6, and KMP subjects are 44.1, this means National exam scores still need to be improved.

According to the National Education Standards Agency the criteria for the achievement of graduate competencies are based on the results of the national exams, the National Examination Score results are reported in the range of grades to 100 with the level of achievement of graduate competencies in the following categories: greater than 85 and smaller than or equal to 100 then good, if the value is greater than 70) and less than or equal to 85 and sufficient, if the value greater than 55 and smaller than or equal to 70 and less, if the value is less than or equal to 55

The average value of the national exam above can be said there are still many students whose grades are lacking, the national exam is one of the results of the teaching and learning process that is influenced by several components, including teachers, students, learning facilities which include facilities and infrastructure in the learning process to compensate for the increase the quality of education it is necessary to increase both in terms of teachers or in terms of facilities and infrastructure or facilities that support learning.

Teacher competence is one of the factors that can affect the level of student achievement, good teacher competence can encourage students to improve their learning achievement. According Wahyudi (2012: 15) Teacher competence is defined as a picture of what should be done by a teacher in carrying out their work, both in the form of activities, behavior and, results that can be addressed. In accordance with Law No. 14 of 2005 article 8 there are four competencies that must be possessed by teachers including pedagogical competencies, personality competencies, social competencies and professional competencies referred to Teacher competencies can affect learning achievement if it includes student pemahan, learning design and implementation, mastery of materials, communicate affective, and can be an example for students.

In addition to teacher competency factors, student motivation is also thought to be a factor that influences the success of the learning process. According to Uno (2011: 23) the nature of learning motivation is internal and external encouragement to students who are learning to make changes in behavior, in general with several indicators or supporting elements. So it is necessary for a teacher to implement a certain learning method that allows the emergence of learning motivation for students. Learning motivation can affect 
learning achievement If there is a desire and desire to succeed, there are encouragement and needs in learning to have hopes or ideals in the future and get an appreciation in learning, there are interesting activities in learning and a conducive learning environment, so as to enable a person students can study well.

Some things that have an important role to be able to produce high-achieving students are by maximizing the way or model of learning or the learning process carried out, Sukaris (2017) states that the right learning model can answer to foster collegiality, cooperation and involvement can improve the quality of the learning process, teacher potential and also learning motivation. Another thing is the use of learning facilities in schools which are the place where the teaching and learning process runs. Learning facilities are facilities and infrastructure used to support learning activities in schools to achieve student success. Sanjaya (2013: 18) states that the completeness of facilities and infrastructure will assist teachers in organizing the learning process so that facilities and infrastructure are important components that can affect the learning process. From this description, learning facilities can affect student achievement if learning facilities include the availability of learning tools, learning spaces or buildings and learning media, both manual and electronic.

Based on this phenomenon learning achievement will be analyzed through teacher competence, student motivation and learning facilities so that the purpose of this study is to determine the effect of teacher competence, student motivation and learning facilities on student achievement.

\section{LITERATURE REVIEW}

Teacher Competency

Wahyudi(2012: 15) Teacher competence is defined as a description of what a teacher should be able to do in carrying out his work, whether in the form of activities, behavior or, results that can be addressed. The definition of competence itself is the ability or ability, in RI
Law No.14 article 1 (10) about teachers and lecturers (2005: 5) explained that: "Competence is a set of knowledge, skills, and behaviors that must be possessed, lived and controlled by a teacher or lecturer in carrying out professional tasks ".

Teacher competencies that must be possessed according to Law No. 14 of 2005 concerning teachers and lecturers article 8 which was quoted from Wahyudi's book (2012:

15) there are four competencies which include the following:

1. Personality competence

Personality competence is a personal ability that reflects a steady, stable, mature, wise and dignified personality, being a role model for students, and having good morals.

2. Pedagogic Competence

Pedagogic competence is the ability of a teacher to manage the learning process of students.

3. Professional Competence

Professional competence is the ability with regard to mastering in-depth learning material that enables it to guide students to meet competency standards.

4. Social Competence

Social competence is the ability to communicate effectively with students, fellow educators, educational staff, parents/guardians of students, and surrounding communities.

Teacher Competency indicators as follows:

1. Personality competence
a. Showing a good work ethic
b. Be a good person
c. Act according to the norm

2. Pedagogic competence

a. Understanding of students

b. The designer and implementation of learning

c. Learning evaluation

3. Professional competence
a. Mastery of learning material
b. Development of learning material
c. Use of technology

4. Social competence 
a. Acting objectively

b. Communicate well

\section{Student Learning Motivation}

Hamzah (2011: 23) the nature of learning motivation is internal and external encouragement to students who are learning to make changes in behavior, in general with several indicators or supporting elements. This learning motivation has a big role in one's success in learning. Based on this understanding, it can be concluded that the understanding of learning motivation is the overall driving force or encouragement in students to carry out learning activities that are marked by changes in energy to achieve the desired goals. Further explained that learning motivation can arise due to intrinsic and extrinsic factors. Intrinsic factors that influence learning motivation are "first, the desire and desire to succeed and the drive for learning needs, and second, expectations of ideals". Extrinsic factors that influence learning motivation include "the first appreciation, secondly, a conducive learning environment, and thirdly, interesting learning activities".

According to Uno (2011: 23), indicators of learning motivation can be classified as follows: Desires and desires to succeed, figures and needs in learning, hopes, and ideals of the future, appreciation in learning, interesting activities in learning, learning environment that is conducive

\section{Learning Facilities}

Dalyono $(2012 ; 59)$ school facilities where learning conditions affect the level of learning success. Learning facilities are facilities and infrastructure used to support learning activities in schools to achieve student success levels. Based on the above understanding, it can be explained that learning facilities are equipment direct and indirect learning that teachers can use to facilitate, expedite and support in student learning activities.
Danim (2010: 17) ideal standards of learning facilities owned by students include the availability of comfortable learning spaces, adequate stationery, the availability of relevant textbooks, adequate vehicle facilities, the availability of desks and chairs for learning, the availability of learning technology media (such as computers, internet, television, adequate communication facilities, learning lighting tools.

\section{Learning Achievement}

Hamdani (2010: 138) Learning achievement is "the measurement results of the learning effort assessment expressed in the form of symbols, letters, and sentences that tell the learning outcomes achieved by each child in a certain period". Surya (2014: 75), namely "learning achievement is the result of learning or changes in behavior regarding science, skills and attitudes after going through certain processes, as a result of the experience of individuals interacting with their environment". After tracing the description above, it can be understood that learning achievement is the result or level of ability that students have achieved after carrying out learning endeavors.

Learning achievement has a close relationship with learning activities, many factors affect learning achievement both originating from within the individual itself or factors originating from outside the individual. Purwanto (2010: 107), factors that influence learning achievement are:

1. Internal factors

Consist of physiological factors. Physiological factors are physical conditions and the five senses. While psychological factors, namely talent, interest, intelligence, achievement motivation, and cognitive abilities.

2. External factors

Consist of environmental factors and instrumental factors. Environmental factors, namely the social environment and the natural environment. While the instrumental factors are curriculum, 
materials, teachers, facilities, administration, and management.

To find out the level of student skills in learning can be seen from the results of learning or learning achievement. Learning achievements obtained through tests or evaluations provide a more general picture of student progress. The success of a teaching if the teaching produces an active and effective learning process.

To find out the level of student skills in learning can be seen from the results or learning achievement. Learning achievement is generally expressed in the form of numbers from 0 to 10 , empirically in school the value obtained can be used as an indicator of high and low learning achievement. Achievement results achieved by students can determine the extent to which students or students can achieve the goals to be achieved.

According to Syah (2013:148) there are several indicators to see student learning outcomes including:

1. In the cognitive domain a The person can be seen from observation, memory, understanding, application, analysis, and synthesis.

2. In the affective domain a The person can be seen from acceptance, greeting, appreciation (attitude of respect), internalization (deepening), and characterization

3. In the psychomotor realm a The person can be seen from his skills in moving and acting, verbal and nonverbal expressions.

Relationship between teacher competence and student learning achievement, According Wahyudi (2012: 15) Teacher competence is defined as a picture of what should be done by a teacher in carrying out their work, both in the form of activities, behavior and, results that can be addressed. Competence possessed by a teacher becomes an important factor in the achievement of student learning achievement (Utomo, Suwachid, \& Suharno, 2012). In education if an educator does not educate with his expertise or ability, then the student is destroyed (Wahyudi 2012; 15). Thus teacher competence has a positive relationship with learning achievement.

The Relationship of Student Learning Motivation with Student Learning Achievement, According to Hamzah B. Uno (2011: 23) the nature of learning motivation is internal and external encouragement to students who are learning to make changes in behavior, in general with several indicators or supporting elements. High learning motivation is one of the factors in getting good learning achievement. The strength of one's learning motivation also influences their success (Dalyono 2015: 56). Thus learning motivation has a positive relationship with learning achievement.

Relationship between Learning Facilities and Student Learning Achievements, Sanjaya (2013: 18) states that "The completeness of facilities and infrastructure will assist teachers in organizing the learning process so that facilities and infrastructure are important components that can influence the learning process. Complete learning facilities will support the smooth teaching and learning process so as to improve student learning achievement. The state of the school where learning also influences the level of student success (Dalyono 2015; 59). Thus learning facilities have a positive relationship with learning achievement.

Based on the theory that has been explained can be stated the following hypothesis: there is a partial effect of teacher competency variables (X1), learning motivation (X2), learning facilities (X3) on student achievement $(\mathrm{Y})$

\section{METHODE}

The approach used in this research is quantitative. The quantitative research method is a method based on the philosophy of positivism used in certain populations or samples Sugiyono (2016). This research was conducted at SMK Muhammadiyah 1 Gresik. 
Population in this study were students of class XII SMK Muhammadiyah 1 Gresik in the academic year 2017/2018 161 students. According to Sugiyono $(2016 ; 81)$ The sample is part of the number and characteristics possessed by the population. In this study, the sample was taken from the population of Muhammadiyah 1 Gresik High School alumni class of 2018. Roscoe in Sugiyono's book (2011: 90) provides suggestions on sample size for research that the sample size that is feasible in research is between 30 to 500 . in this study, researchers took a sample of 100 . As a general rule, the sample size between 30 and 500 can be effective depending on the sampling technique used and study questions are used

Technique used in this study is Non Probability sampling is sampling incidental. Sampling Incidental according to (Sugiyono, 2016: 85) sampling technique based on the chance that anyone who incidentally / incidentally met with the researcher can be used as a sample if it is seen that people who happen to be found suitable as a source of data.

The type of data used in this study is primary data. According to Sugiyono (2016: 137) defines primary data as a source of data that directly provides data to data collectors. The research data was obtained from respondents who had filled out the research questionnaire. Respondents directly provide their opinions through a questionnaire that already contains a measurement scale for each variable. Primary data used in this study are data that contain teacher competencies (X1), learning motivation (X2), and learning facilities (X3).

Data collection techniques used are using a questionnaire. According to Sugiyono (2012: 142) "Questionnaire or questionnaire is a data collection technique that is done by giving a set of questions or written statements to respondents to be answered". The instrument or tool used to collect data is a questionnaire. The data taken is primary data.

The measurement technique used in this study is to use a Likert scale. According to
Sugiyono (2017; 93) with a Likert scale, the variables to be measured are translated into indicator variables. Likert scale is used to measure the attitudes, opinions, and perceptions of a person or group of people about social phenomena. The likert scale used in this study is a range of 1-5 Likert Scale

Test Instrument, the validity test shows the extent to which a measuring device that measures what you want measuring. To test the validity in this study is to calculate the correlation between each statement with a total score using the correlation product moment. The validity of an item is known by comparing the correlation coefficient index productmoment (r) with its critical value. Test Reliability, Reliability stability and consistency of an instrument that measures a concept. A reliability test is a tool to measure a questionnaire which is an indicator of a variable or constructs. A questionnaire is said to be reliable or reliable if someone's answer to the question is consistent or stable from time to time (Ghozali, 2016; 47). Respondents' answers are said to be reliable if each question is answered consistently (Ghozali, 2016; 48). SPSS provides facilities to measure reliability with statistical tests Cronbach Alpha. A variable is said to be reliable if it gives a value Cronbach Alpha> 0.70 (Nunnally, 1994 in Ghozali, 2016; 48).

Classical Assumption Testing, this test includes multicollinearity testing, Heterokedasticities Test, Normality Test. Furthermore, Data Analysis Techniques in research use Multiple Linear Regression Analysis which is a technique that explains the dependence of dependent variables with one or more independent. In this analysis, the relationship between one dependent variable and one independent variable can be measured.

The multiple linear regression analysis model is: $\mathrm{Y}=\mathrm{a}+\mathrm{b} 1 \mathrm{x} 1+\mathrm{b} 2 \mathrm{x} 2+\mathrm{b} 3 \times 3+\mathrm{e}$. Where: $\mathrm{Y}=$ Learning achievement (dependent variable), $\mathrm{X} 1=$ Teacher competence, $\mathrm{X} 2=$ Learning motivation, $\mathrm{X} 3$ = Learning facilities, a 
= Constant, b1; b2; b3 = Regression Coefficient and $\mathrm{e}=$ Error

Testing Coefficient of Determination $\left(\mathrm{R}^{2}\right)$, According to Ghozali (2013: 97) coefficient of determination $\left(\mathrm{R}^{2}\right)$ basically measures how far the model's ability to explain variations in the dependent variable. The coefficient of determination is between zero and one. A small R2 value means that the ability of independent variables to explain the variation of the dependent variable is very limited. A value close to one means that the independent variables provide almost all the information needed to predict the variation of the dependent variable. In general, the coefficient of determination for the data cross(cross-section)is relatively low due to the large variation between each observation, while for the timeseries data(time-series)usually has a high coefficient determination. The

fundamental drawback of using the coefficient of determination is the bias towards the number of independent variables entered into the model. Every additional one independent variable, then $\mathrm{R} 2$ must increase regardless of whether the variable significantly influences the dependent variable. Therefore many researchers suggest using the value Adjusted $\mathrm{R}{ }^{2}$ when evaluating which regression model is best. Unlike $\mathrm{R}^{2}$, the value Adjusted $\mathrm{R}^{2}$ can go up or down if an independent variable is added to the model.

Hypothesis testing, Before testing is carried out, the significance level must first be determined. This is done to make a test plan so that the boundaries are known to determine the choice between the null hypothesis (Ho) and the alternative hypothesis (Ha). The significance level chosen and determined in this study was $0.05(\alpha=0.05)$ with a confidence level of $95 \%$. This figure was chosen because it can represent the relationship of the variables studied and is a level of significance that is often used in research in the field of Social Sciences. The test criteria used are:

1. If the significance level $<(\alpha=0.05)$, then Ho is rejected and Ha is accepted, meaning that there is a significant influence between one variable on the independent variable.

2. If the significance level $>(\alpha=0.05)$, then $\mathrm{Ho}$ is accepted and $\mathrm{Ha}$ is rejected, meaning that there is no significant influence between one variable on the independent variable.

\section{RESULTS AND DISCUSSION}

The validity of Test Results In this study used a questionnaire to collect research data. A questionnaire is said to be valid if the statement on the questionnaire is able to reveal something that will be measured by the questionnaire. In this validity test, the contents of a statement or variable are said to be valid if rcount is greater than rtable. The reliability test results show that all items used are reliable

The results of the classical assumption test which consists of multicollinity test, heteroscedasticity test, and normality test

Multiple Linear Regression Analysis in this study is used to determine whether the variable Teacher Competence (X1), Learning Motivation (X2), and Learning Facilities (X3) affect the Student Learning Achievement, based on the data processing carried out can be made of the multiple linear regression equation above can be explained as follows: $\mathrm{Y}=-1,469+$ $0,208 \mathrm{X} 1+0,412 \mathrm{X} 2+0,771 \mathrm{X} 3+\mathrm{e}$ where ;

1. The constant value (a) of 1,469 indicates that if SMK Muhammadiyah 1 Gresik does not make changes to Teacher Competence (X1), Learning Motivation (X2), and Learning Facilities (X3), then the magnitude of the Learning Achievement variable $(\mathrm{Y})$ is 1,469 units.

2. The value of the Teacher Competency regression coefficient (X1) of 0.208 . These results indicate that good Teacher Competency, if improved, will increase student learning achievement. Conversely, if Teacher Competency is poor it will reduce student learning achievement. With SMK Muhammadiyah 1 Gresik there is no 
change in learning motivation and learning facilities

3. The regression coefficient of Learning Motivation (X2) is 0.412. These results indicate that if students' learning motivation increases they will improve student learning achievement at SMK Muhammadiyah 1 Gresik. Conversely, if student motivation decreases student achievement in SMK Muhammadiyah 1 Gresik will also decrease. Assuming that SMK Muhammadiyah 1 Gresik does not make changes to Teacher Competencies and Learning Facilities.

4. The Learning Facilities (Xregression coefficient value3)of 0.711 . These results indicate that if SMK Muhammadiyah 1 Gresik increases its student learning facilities it can improve student learning achievement. Conversely, if learning facilities are not improved it can reduce student achievement in SMK Muhammadiyah 1. Assuming that SMK Muhammadiyah 1 Gresik does not make changes in Teacher Competence and Student Learning Motivation

Correlation coefficient (R) is used to determine the relationship between independent variables $(\mathrm{X})$ to the dependent variable $(\mathrm{Y})$ together. The coefficient of determination () basically measures the ability of the model to explain the variation of independent variables. The results of the data olag show the R Square value Adjusted $=0.912$ it can be said that the change in the dependent variable (Y) of $91.2 \%$ is caused by the variables of Teacher Competence (X1), Learning Motivation (X2), and Learning Facilities (X3), while the rest $7.8 \%$ can be explained by other factors outside the variable.

The hypothesis of this study is that there is a partial effect of the variable Teacher Competence (X1), Learning Motivation (X2), Learning Facilities (X3) on Student Learning Achievement (Y), the results of the study show:

1. Teacher Competencies that significant value (X1) of $0,003<$ of $\alpha$ significance level
(0.05), then H0 is rejected and Ha accepted, which means Teacher Competence (X1) is a partially significant effect on the achievement learning $(\mathrm{Y})$.

2. That significant value learning motivation variable (X2) of $0.000<$ of $\alpha$ significance level (0.05), then $\mathrm{HO}$ is rejected and $\mathrm{Ha}$ accepted, which means learning motivation variable (X2) partially significant effect on the achievement learning (Y).

3. That the value of the variable significance Learning Facility (X3) $0,000 \quad<$ of $\alpha$ significance level (0.05), then $\mathrm{H} 0$ is rejected and $\mathrm{Ha}$ accepted meaning variable Learning Facility (X3) partially affects the achievement learning $(\mathrm{Y})$.

Based on research and data analysis can be interpreted in the discussion as follows:

1. Effect of Teacher Competence on learning achievement.

The results showed that Teacher Competence had a positive and significant effect on Student Learning Achievement. Positive results have the meaning of increasing Teacher Competence, the Student Learning Achievement is increasing. Significant results mean that Teacher Competency is able to be a factor that influences Student Learning Achievement. Teacher Competency will increase if it is able to meet the following indicators: 1) Personality competence which includes showing a good work ethic, being a good person, acting according to norms 2 ) Paedagogic competence which covers students' understanding, design and implementation of learning, learning evaluation 3) Professional competence which includes mastery of learning material, development of learning material, use of technology 4) Social competence which includes acting objectively and communicating well. According to (Utomo, Suwachid, \& Suharno, 2012) the competency of a teacher is an important factor in the achievement of student 
learning outcomes. teacher towards student learning outcomes.

2. The Effect of Learning Motivation on Student Achievement

The results of the study show that Learning Motivation has a positive and significant effect on Student Achievement. Positive results have the meaning of increasing Learning Motivation then increasing Student Learning Achievement. Significant results have meaning that Learning Motivation is able to be a factor that influences Student Learning Achievement. Learning motivation will increase if it is able to meet the following indicators: desire and desire to succeed, encouragement and needs in learning, hopes and aspirations for the future, appreciation in learning, interesting learning activities, a conducive learning environment. According to Dalyono $(2015 ; 56)$ The strength of one's learning motivation also influences their success. Thus learning motivation has a positive relationship with learning achievement. The results of this study are in accordance with previous research conducted by Lilik Agustina, Rustiyarso, Okiana (2016) proving that there is an influence of student learning motivation on sociology learning outcomes at SMA Kemala Bhayangkari 1 Sungai Raya, Kubu Raya Regency.

3. The Effect of Learning Facilities on Student Achievement

The results of the study showed that Learning Facilities had a positive and significant effect on Student Achievement. Positive results have the meaning of increasing Learning Facilities, the Student Learning Achievement is increasing. Significant results have the meaning that Learning Facilities can be a factor that influences Student Learning Achievement. Learning facilities will improve if they are able to meet the following indicators: Building conditions, Classrooms, Libraries, Completed textbooks, Learning equipment.
According to (Dalyono 2015; 59) The state of the school where learning also influences the level of success of students. Thus learning facilities have a positive relationship with learning achievement. The results of this study are consistent with previous research conducted by Ranti Yayu Triana (2016) which states learning facilities can have a positive influence on the learning process in the classroom and can improve student learning outcomes of the class.

\section{CONCLUSION}

Based on the results of data analysis and results presentation, it can be concluded that teacher competence influences student achievement, learning motivation affects student achievement and learning facilities affect student achievement. Managerial implications, to improve learning achievement in schools can be done through continuously improving teacher competence, student motivation, and learning facilities. The implication for further research is that it can be used as a reference by adding variables out of control (variables that cannot be controlled) as moderation variables that can strengthen learning achievement.

\section{REFERENCES}

Arifin, Z. (2011). Penelitian Pendidikan Metode dan Paradigma Baru. Bandung : PT Remaja Rosdakarya.

Arikunto, Suharsimi. (2010). Prosedur Penelitian Suatu Pendekatan Praktik. Jakarta: Rineka Cipta

BSNP. (2017). Prosedur Operasional Standar Penyelenggaraan Ujian Nasional. Jakarta: Badan Standar Nasional Pendidikan.Tersediadalam:http://bsnpiin donesia.org/wpcontent/uploads/2017/01/ 0043-POS-UN-Tahun-2017 FINAL.pdf.

Citra Choiruniza Rizqi Devi. (2016). Pengaruh Kompetensi Guru Terhadap Hasil Belajar Siswa Kelas V Sdn Nogotirto 
Dalyono. (2012). Psikologi Pendidikan. Jakarta : Rineka Cipta.

Danim, Sudarwan. (2010). Pengantar Kependidikan.Bandung : Alfabeta

Depdiknas .2003. Undang-undang RI No.20 tahun 2003.tentang sistem Pendidikan nasional.

Devi Ayu Kusuma Putri, Bambang Wasito Adi - -, Sunarto - (2016) Pengaruh sarana Prasarana Sekolah Dan Motivasi Belajar Siswa Terhadap prestasi Belajar Siswa Pemasaran Di Smk Negeri 1 Sukoharjo Tahun ajaran 2015/2016.Vol.2.no.2

Ghozali, Imam. (2016). "Aplikasi Analisis Multivariate dengan Program SPSS “. Semarang : UNDIP.

Hamdani. (2010). Strategi Belajar Mengajar. Bandung : Pustaka Setia

Hamzah B. Uno. (2011). Teori Motivasi dan Pengukurannya: Analisis di Bidang pendidikan. Jakarta: Bumi aksara
Imam wahyudi. (2012). Panduan Lengkap Uji Sertifikasi Guru. Jakarta:PT Prestasi pustakaraya.

Purwanto, Ngalim. (2010). Prinsip-Prinsip dan Teknik Evaluasi Pengajaran. Bandung: PT. Remaja Rosdakarya.

Sanjaya. Wina. (2010). Strategi Pembelajaran “Berorientasi Standart Proses". Jakarta: Prenada Media Group.

Sopiatin, Popi. (2010). Manajemen Belajar Berbasis Kepuasan Siswa. Bogor: Ghalih Indonesia.

Sugiyono. (2016). Metode Penelitian Kuantitatif, Kualitatif, dan $R \& D$.Bandung: Alfabeta.

Sukaris, S. (2017). Model Pembelajaran Lesson Study Terhadap Motivasi Belajar Mahasiswa Melalui Kualitas Proses Pembelajaran Dan Kompetensi Dosen. Jurnal Manajerial, 2(1), 17-26 